University of Nebraska - Lincoln

DigitalCommons@University of Nebraska - Lincoln

Faculty Publications from the Harold W. Manter Laboratory of Parasitology

$12-1992$

\title{
Dynamics of the Arctic Fox Population on St. Lawrence Island, Bering Sea
}

Francis H. Fay

University of Alaska Anchorage

Robert L. Rausch

University of Washington, rausch@u.washington.edu

Follow this and additional works at: https://digitalcommons.unl.edu/parasitologyfacpubs

Part of the Parasitology Commons

Fay, Francis H. and Rausch, Robert L., "Dynamics of the Arctic Fox Population on St. Lawrence Island, Bering Sea" (1992). Faculty Publications from the Harold W. Manter Laboratory of Parasitology. 556. https://digitalcommons.unl.edu/parasitologyfacpubs/556

This Article is brought to you for free and open access by the Parasitology, Harold W. Manter Laboratory of at DigitalCommons@University of Nebraska - Lincoln. It has been accepted for inclusion in Faculty Publications from the Harold W. Manter Laboratory of Parasitology by an authorized administrator of DigitalCommons@University of Nebraska - Lincoln. 


\title{
Dynamics of the Arctic Fox Population on St. Lawrence Island, Bering Sea
}

\author{
F.H. FAY ${ }^{1}$ and R.L. RAUSCH ${ }^{2}$
}

\author{
(Received 8 August 1991; accepted in revised form 6 February 1992)
}

\begin{abstract}
We hypothesized that the arctic fox. Alopex lagopus (Linnaeus), population on St. Lawrence Island was cyclic and that its fluctuations in size, structure, and productivity were correlated with the relative size of the population of northern voles, Microtus oeconomus Pallas, the primary prey. Based on a nine-year study, we determined that the variations in size of the fox and vole populations were similar, but they both were of low amplitude and not closely correlated. The high pregnancy rate (mean, $86 \% / y r)$ and numbers of young conceived (mean, $11.5 / \mathrm{pregnancy}$ ) did not vary significantly among years, probably because of the consistently abundant and diverse food supply available to the foxes. The age composition of the trappers' catch of foxes each winter also was comparatively stable, but it was closely correlated with the size of the vole population in the previous summer. The survival of the young foxes during the summer probably was dependent on the availability of the voles. The composition of the catch also appeared to be influenced by immigration of foxes from the adjacent continents via the pack ice.
\end{abstract}

Key words: Bering Sea, arctic fox, Alopex lagopus, population dynamics

RÉSUMÉ. Nous avons émis l'hypothèse que la population du renard arctique, Alopex lagopus (Linnaeus), sur l'île Saint Lawrence élait cyclique et que les fluctuations concernant sa taille. sa structure et sa productivité étaient corrélées à la taille relative de la population du campagnol nordique, Microtus oeconomus Pallas, sa principale proie. En nous appuyant sur une étude menée sur neuf ans, nous avons déterminé que les variations dans la taille des populations du renard et du campagnol étaient semblables, mais que toutes deux avaient une faible amplitude et n'élaient pas corrélées de façon étroite. Le taux de grossesse élevé (moyenne $86 \mathrm{p}$. cent/an) et le nombre de petits conçus (moyenne $11.5 /$ grossesse) ne variaient pas de façon significative au cours des ans, probablement à cause de l'abondance et de la variété de sources de nourriture pour les renards. La composition d’ấge des prises des trappeurs était également stable d'un hiver à l'autre, mais elle était corrélée de façon étroite avec la taille de la population de campagnols au cours de l'été précédent. La survie des renardeaux au cours de l'été dépendait probablement de la disponibilité des campagnols. La composition des prises semblait aussi être influencée par l'immigration des renards venant des terres continentales adjacentes par la voie de la banquise.

Mots clés: mer de Béring, renard arctique, Alopex lagopus, démécologie

Traduit pour le journal par Nésida Loyer.

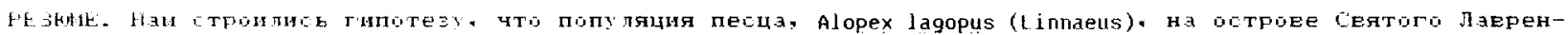

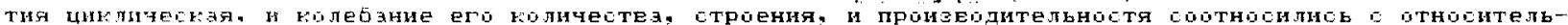

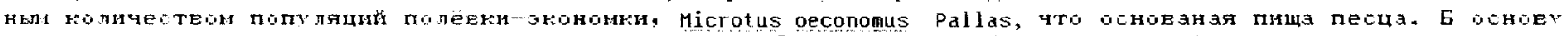

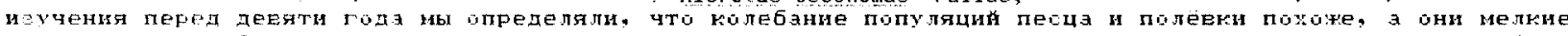

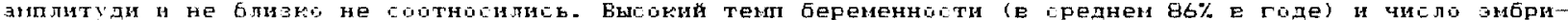

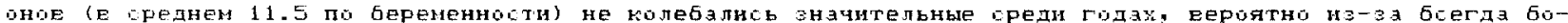

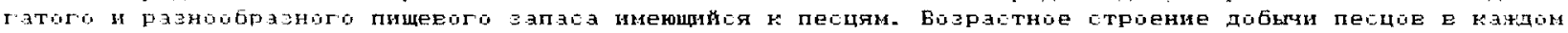

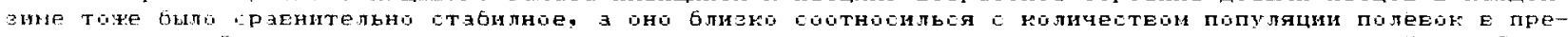

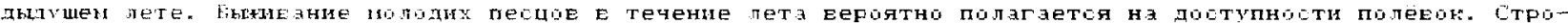

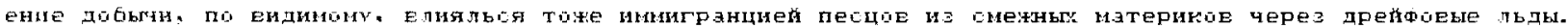

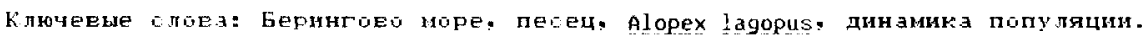

\section{INTRODUCTION}

The arctic fox, Alopex lagopus (L.), is a furbearer of considerable economic importance to human residents at high northern latitudes (Vibe, 1967; Smirnov, 1968; Macpherson, 1969; Chesemore, 1972). Throughout the Arctic, it is important also as a carrier of pathogens lethal to man, namely, the virus of rabies and the cestode Echinococcus multilocularis Leuckart, the causative agent of alveolar hydatid disease (AHD) (Secord et al., 1980; Rausch, 1986). On St. Lawrence Island, where both rabies and AHD are especially prevalent (Rausch and Schiller, 1956; Rausch, 1958, 1968, 1972), studies of the epidemiology of those diseases have been under way for more than 40 years. Included early in those studies was a 9-year investigation of the arctic fox population (1953-61) directed toward understanding the influence of its variation in size and that of its rodent prey on the transmission of those diseases (Fay, 1973).

This paper reports on the results of that 9-year investigation as regards the dynamics of the fox population. It was begun with the working hypothesis that the size of the fox population, its age composition, and its productivity were positively correlated with each other and that each of those characters was positively correlated as well with the cycling of the island's population of rodents. The presumed relationship with the rodents was based on the knowledge that the northern vole, Microtus oeconomus Pallas, the most abundant arvicoline on the island (Murie, 1936; Rausch, 1953), is an important item in the diet of the foxes (Fay and Stephenson, 1989) and that its population appeared to fluctuate with a 3- to 4-year frequency (Rausch and Schiller, 1956). Since this is an island surrounded by sea ice for at least six months of the year, we supposed that immigration and emigration of foxes via the pack ice also would exert some influence on both the size and composition of the fox population.

\section{METHODS}

We collected three types of information: 1) the relative size of the fox population on the island in the autumn each year, 2) the composition of the trappers' catch of foxes each winter in terms of sex, age, and reproductive status, and 3) the relative size of the northern vole population each summer.

The information on relative size of the fox population consisted of verbal reports from several of the more successful

${ }_{1}$ Institute of Marine Science, University of Alaska, Fairbanks, Alaska 99775, U.S.A.

${ }^{2}$ Department of Comparative Medicine, University of Washington, Seattle, Washington 98195, U.S.A.

OThe Arctic Institute of North America 
fox trappers, complemented by measurements of the rate of accrual of the catch. At the time of this study, the Yup'ik inhabitants of the island resided in three villages, Gambell, Savoonga, and Northeast Cape (Fig. 1). Between 20 and 40 men from the village of Gambell trapped foxes on the western onethird of the island, and between 25 and 50 from the villages of Savoonga and Northeast Cape trapped on the eastern twothirds. The trappers' perceptions of the relative size of the fox population each year were based on the numbers of foxes they saw and caught per day and their interpretation of other signs, such as the relative abundance of tracks in the snow and the sites where foxes had dug in the snow for food. Their awareness of changes in the fox population each year was keenest in November and December.

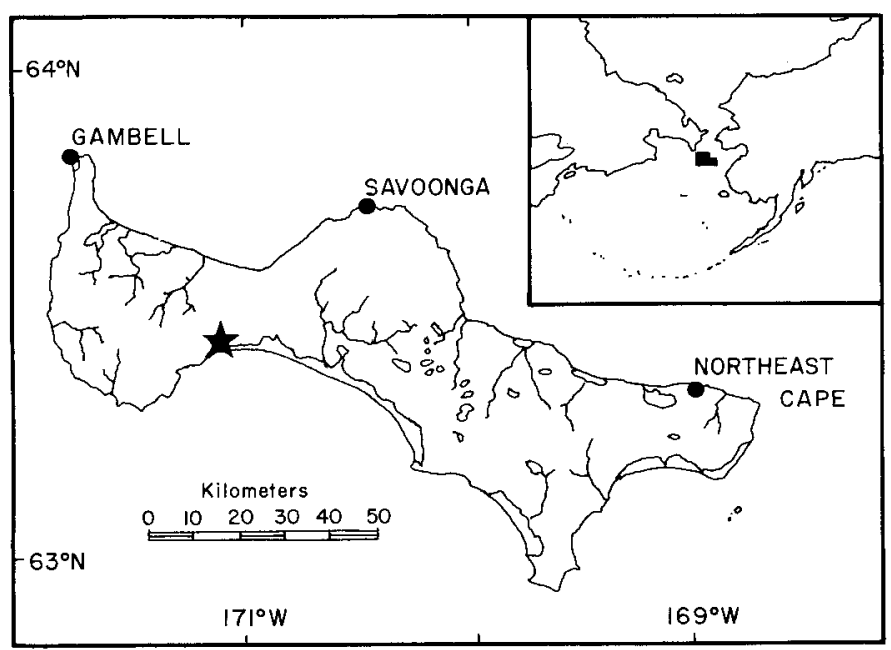

FIG. I. Map of St. Lawrence Island, showing the locations of the three Yup'ik villages extant at the time of this study and the site (star) in which the vole population was measured. Inset at upper right shows location in relation to Alaska and Chukotka.

In November, each trapper established a series of bait stations on the tundra, around which he would later set his traps. The baits consisted of chunks of flesh salvaged from naturally occurring beach-cast carcasses of marine mammals. Such carrion is one of the primary foods of the island's foxes during the winter (Fay and Stephenson, 1989). To prevent their baits from being consumed by the foxes, the trappers covered the baits with driftwood and rocks. They generally visited the baits several times before the trapping season opened to maintain the covering and to take note of the tracks and other signs of fox activity. At the opening of the season, on 1 December, a small part of the covering was removed to allow the foxes limited access to the baits, and usually two traps were set in the snow at each station. The traps were inspected daily during December and less often as the catch declined in the subsequent months. When the catch per unit effort decreased below some threshold, the traps were retrieved and the trapping ceased.

The trappers' efforts were essentially equal among years in November and December, except in the winter of 1956-57, when the density of the fox population was perceived early as being very low. In that winter, many of the trappers turned to other pursuits by mid-December, after their initial efforts yielded a very poor catch of foxes. Also in years when foxes were scarce later in the season, the retrieval of traps often took place well before the trapping season officially ended (15 April).
In the winter of 1953-54 and each winter from 1955-56 to 1961-62, we purchased a sample of 100 or more skinned carcasses of foxes from the trappers in the beginning of the trapping season. Our request for that sample each year was placed well before 1 December; hence we routinely obtained the first foxes that were caught. Since the carcasses were labelled with the date of capture, we could measure the rate of accrual of the catch each year in terms of the cumulative number caught per day. The rate of accrual of the trapped samples, therefore, was a quantitative expression, complementary to the trappers' qualitative assessment of the relative abundance. It allowed statistical comparison among years and examination of relationships of fox numbers with other parameters of the fox and prey populations. In 1960 and 1961, most of the carcasses were of females (by our request) drawn selectively from the catch, so we adjusted the accrual rate for the unbalanced sex ratio in those two years.

Ages of the carcasses were determined from dental characters. Most of the young of the year were identified from the thin walls and large volume of the pulp chamber in their canine teeth, as noted also by Grue and Jensen (1976) and Bradley et al. (1981). Ages of the adults and of specimens not certainly identified as young were determined by counting the number of annual layers of cementum in thin, finely ground, sagittal sections of the roots of the upper canine teeth, examined under 10-30x magnification. We also recorded the number of placental scars or fetuses in the uterus of each adult female. We counted only the scars having uniform, dark coloration, assuming that they were all from the latest pregnancy. In some cases, paler scars were present as well, apparently from a previous pregnancy, but these were not counted because some of them appeared to have been obscured by the more recent ones. In two cases where there was a gradient in coloration of the scars, we discarded the specimens because we could not be certain which of the scars were from the latest pregnancy. The number of recent scars was assumed to be indicative of at least the number of young conceived in the latest pregnancy, though not necessarily of the number of pups born (e.g., see Lindström, 1981).

Our assessment of the relative density of the northern vole population on the island was interpreted from annual snaptrapped samples at a site on the southern coast (Fig. 1) in July and August, which is the time of maximal numbers each year. Two traplines, each $980 \mathrm{ft}$ ( $299 \mathrm{~m}$ ) long, were situated in an area of wet to well-drained tundra, typical of about $60 \%$ of the island's vole habitats. Along each line, numbered stakes were erected permanently at $20 \mathrm{ft}(6 \mathrm{~m})$ intervals, and three snaptraps were set in established runways within $6 \mathrm{ft}(1.83 \mathrm{~m})$ of each stake (in the manner of Pitelka, 1973). The traps were tended twice per day, usually at 0700 and $1400 \mathrm{~h}$, and the index of relative abundance was the average number of voles captured per trap per day during the first $72 \mathrm{~h}$ of trapping.

\section{RESULTS}

\section{Relative Size of the Fox Population per Year}

The trappers judged that the fox population was high during five of the nine years of record, low during only one, and otherwise about average (Table 1). That judgement was upheld by the rate of accrual of our samples from the catch (Fig. 2), which showed comparable shifts. The lowest accrual differed by an order of magnitude from the highest, and each of the 
TABLE 1. Description of the annual winter samples of fox carcasses in comparison with the relative density of the fox and vole populations on St. Lawrence Island, Alaska

\begin{tabular}{|c|c|c|c|c|c|c|c|}
\hline \multirow[b]{2}{*}{ Year } & \multicolumn{2}{|c|}{ Relative size of fox population } & \multicolumn{2}{|c|}{ Composition of foxes caught in December } & \multicolumn{2}{|c|}{ Mean reproductive characters of vixens } & \multirow{2}{*}{$\begin{array}{l}\text { Relative density of } \\
\text { vole population } \\
\text { (no. voles caught } \\
\text { per trap-day) }\end{array}$} \\
\hline & Trapper reports & Accrual rate ${ }^{a}$ & $\mathrm{M} / \mathrm{F} \quad(\mathrm{n})$ & $\%$ yg (n) & Pregnant $\% \quad(n)$ & Plac. scars no. (n) & \\
\hline 1953 & high & 78 & $1.28 \quad(74)$ & $99 \quad(73)$ & - & - & $(\text { high })^{b}$ \\
\hline 1954 & average & - & - & - & - & - & $(\text { high })^{c}$ \\
\hline 1955 & high & 100 & $1.17(200)$ & $92(200)$ & $94(16)$ & $11.1(15)$ & $(0.05)^{\mathrm{d}}$ \\
\hline 1956 & low & 9 & $0.79 \quad(88)$ & $83(87)$ & $100(11)$ & $11.1(11)$ & 0.01 \\
\hline 1957 & high & 59 & $1.24(202)$ & $94(200)$ & $80(15)$ & $10.1(11)$ & 0.08 \\
\hline 1958 & high & 61 & $1.23(98)$ & $94(118)$ & $85(20)$ & $12.3(15)$ & 0.11 \\
\hline 1959 & average & 29 & $1.50(100)$ & $95(101)$ & $76(25)$ & $11.9(19)$ & 0.06 \\
\hline 1960 & average & 40 & $-^{c}$ & $97(107)$ & $100 \quad(5)$ & $14.5 \quad(4)$ & 0.08 \\
\hline 1961 & high & 100 & $\square^{c}$ & $99 \quad(99)$ & $100 \quad(2)$ & $9.5 \quad(2)$ & $(0.11)^{d}$ \\
\hline
\end{tabular}

${ }^{a}$ Percent of the catch sample obtained in the first five days of December, when $\mathrm{n}=100$. Catches in 1960-61 were adjusted for selective sampling.

${ }^{\mathrm{b}}$ Reported by Rausch and Schiller (1956).

"General evaluation by Yup'ik observers and the authors.

"Estimated from results other than in July-August or from non-standard traplines.

"Samples biased by selection of mainly females from the catch.

accrual rates differed significantly from the others (Kolmogorov-Smirnov statistics 0.22 to $0.93, p=0.0158$ to $<0.0001$ ).

In three years $(1955,1957,1958)$, the density of the population was judged to have been high in the autumn but to have declined markedly when the drifting pack ice first reached the island in late November or early December. Those declines were attributed to emigration onto the ice by a high proportion of the island's foxes. Marked increases in the catch also were reported, ostensibly as a result of immigration from the ice.

\section{Composition of the Samples from the Catch}

Over the nine-year period, we obtained 1322 pelted carcasses of arctic foxes, 1116 of which were in bisexual samples drawn at random from the catches, and 206 of which were mainly females selected from the catches in December 1960 and 1961. The sex ratio in the bisexual samples was skewed slightly toward males but did not differ significantly from unity $\left(577: 515, X_{(1)}^{2}=1.76, p=0.1844\right)$.

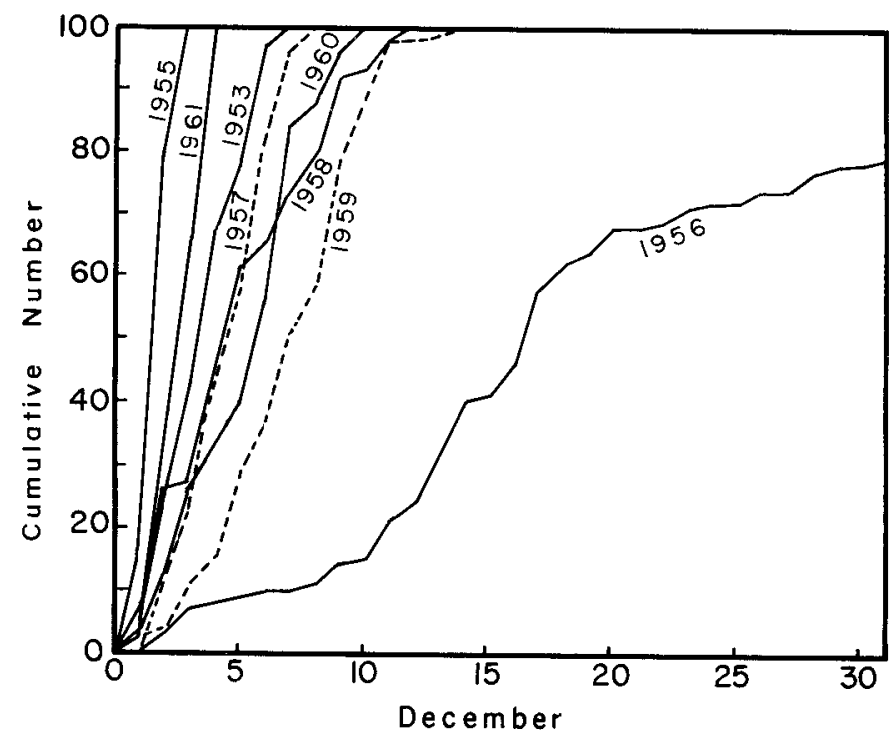

FIG. 2. Comparative accrual rates per year of the trapped samples of foxes in terms of the cumulative numbers per day in December. $\mathrm{N}=100$ for each sample.
The samples obtained in December each year showed a preponderance of young of the year (Table 1). After December, however, the proportion of young in the catch declined steadily (Table 2), indicating that the age composition of the population also had changed. By April, adults and young were about equally represented in the catch.

TABLE 2. Ratio of young of the year to adult foxes in pooled monthly samples from St. Lawrence Island, 1953-61

\begin{tabular}{lccc}
\hline \hline Month & No. of young & No. of adults & \% young \\
\hline December & 924 & 61 & 94 \\
January & 13 & 7 & 65 \\
February & 55 & 22 & 71 \\
March & 90 & 64 & 58 \\
April-May & 29 & 30 & 49 \\
\hline \hline
\end{tabular}

The age composition of the adults did not appear to vary among years - that is, there were no strong or weak cohorts that could be identified from year to year. Adults 1-3 years old were well represented in all years, and animals 4-7 years old were not uncommon. The oldest adult was 8 years old. The mean survival rate of adults, indicated by the frequency of occurrence of age classes in the pooled samples (Fig. 3), was about 0.75 per year.

\section{Productivity}

The number of placental scars per pregnancy varied from 5 to 20, with a mean of $11.5(\mathrm{n}=77)$. The annual means (Table 1) did not differ significantly from each other (Kruskal-Wallis statistic $8.4042, \mathrm{p}=0.210$ ). The pregnancy rates (mean, $86.2 \%$ per year, $n=94$ ) also showed no significant variation among years (Kruskal-Wallis statistic $=6.2649, \mathrm{p}=0.3942$ ).

\section{Relative Size of the Vole Population}

The relative density of the northern vole population showed trends that were similar to those of the foxes but not entirely consistent with them (Table 1). Apparently, the voles were at their lowest in 1956, as were the foxes, but the highest density of voles occurred in 1958 and 1961, rather than in 1955 and 


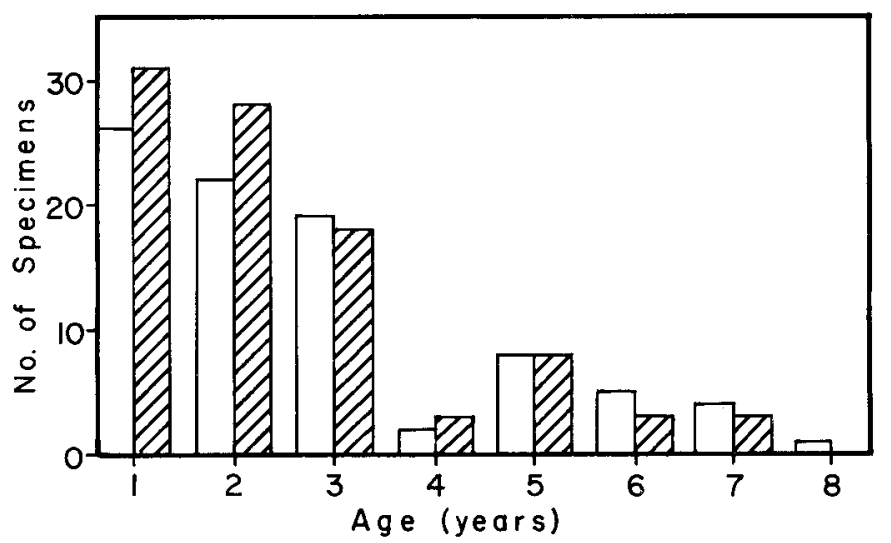

IIG. 3. Histogram of age composition of the adult males (open bars) and females (cross-hatched) in the samples of arctic foxes drawn from the trappers' catch on St. Lawrence Island, 1953-61.

1961, and there was no significant correlation overall between the fox catch and the relative density of the vole population $\left(\mathrm{r}^{2}\right.$ $=-0.03060,5$ d.f., $p=0.1977$ ).

\section{Other Correlations}

Assuming that the composition of the catch was reflective of but not necessarily equal to the composition of the fox population, we compared the annual proportion of young in the December samples with our indexes of the relative size of the fox population (rate of accrual) each year. When the young: adult ratio was highest $(1953,1961)$, the population also was high, and when the ratio was lowest (1956), the population also was low, but there was little correspondence between them otherwise and no significant correlation overall $\left(r^{2}=0.1977,6\right.$ d.f., $p=0.1439$ ).

The annual means of pregnancy rate and numbers of placental scars were not correlated with each other (weighted $r^{2}=$ $-0.20,5$ d.f., $p=0.991$ ), and neither pregnancy rate nor number of scars was correlated with the accrual rate (weighted pregnancy $r^{2}=0.0414,5$ d.f., $p=0.662$; weighted scars $r^{2}=$ $0.0671,5$ d.f., $p=0.575$ ). Neither the pregnancy rate nor the mean number of placental scars per year was correlated with the vole population index (weighted $\mathrm{r}^{2}$ for pregnancy $=0.1287$ and scars $=0.0574 ; 5$ d.f. each; $\mathrm{p}=0.4294$ and 0.6048 ). Furthermore, in all but one year (1956), the proportion of young in the December samples exceeded the proportion predicted (range $80-88 \%$, mean $83 \%$ ) from the pregnancy rate and placental scars, assuming a balanced sex ratio of adults, and there was no significant correlation between the observed and predicted values $\left(\mathrm{r}^{2}=0.0086,5\right.$ d.f., $\left.\mathrm{p}=0.8429\right)$. The proportion of young in the December samples also was not correlated with either the pregnancy rate $\left(r^{2}=0.3133,5\right.$ d.f., $p=$ $0.1913)$ or the mean number of placental scars each year $\left(r^{2}=\right.$ $0.0680,5$ d.f., $p=0.572$ ), but it was correlated significantly with the vole density $\left(r^{2}=0.7259,5\right.$ d.f., $\left.p=0.0149\right)$.

\section{DISCUSSION}

At the outset of this study, we assumed that the arctic fox population on St. Lawrence Island would be cyclic in size, composition, and productivity, and that its fluctuations would be in concert with the cycling of the vole population there. This was based on the observations of Rausch and Schiller (1956) concerning the role of those fluctuations in the epi- zootiology of AHD and the general knowledge at that time of fox-rodent cycles in the Arctic (e.g., Pedersen, 1930; Chitty and Elton, 1937; Braestrup, 1941; Elton, 1942). Most of the results, however, upheld the null hypothesis. Neither the fox nor the vole population was clearly cyclic, and their variations in relative size, although similar, were of low amplitude and not in close synchrony. Furthermore, the productivity of the foxes was comparatively high in all years and not clearly related to density of either the fox or the vole populations. The proportion of young of the year in the trappers' catch, however, was closely correlated with the relative size of the vole population, as was the frequency of occurrence of voles in the diet of the foxes (Fay and Stephenson, 1989). Those relationships suggest that the density of the vole population had a considerable influence on the rate of survival of the young foxes during the summer.

The annual productivity of the St. Lawrence Island foxes and the proportion of young in the catch were higher and more stable than has been reported for most other populations (cf. Braestrup, 1941; Shibanov, 1951; Chirkova, 1958a,b; Macpherson, 1969; Cherniavskii and Dorogoi, 1981; Novikov, 1985; Garrott and Eberhardt, 1987), probably because of the abundance and diversity of foods available to them. They have access to voles at comparatively high densities nearly every year, as well as to large colonies of cliff-nesting birds and plenty of carrion (Fay and Stephenson, 1989). Probably because of that abundance, the linkage of their productivity and population changes with those of the rodents alone is not as close on the island as it is in continental localities where food sources are less diverse and there is greater dependence on arvicoline rodents (e.g., Macpherson, 1969).

Productivity and survival alone were not enough to account for the high proportion of young in the catch, however, for the quantity of young exceeded the predicted proportion by $10 \%$ or more in every year but one. We suppose that the difference could have been attributable to trap-proneness of the young foxes, but we suspect that it was attributable primarily to immigration of foxes via the pack ice. The trappers' assertions that their catches were made up not only of foxes born on the island but of a significant proportion of immigrants as well were supported by the occasional occurrence there of arctic foxes with parasites that they could have acquired only on the continents (Rausch et al., 1990).

Arctic foxes are well known as travellers over the pack ice, as well as over land, sometimes passing thousands of kilometres from their point of origin (Chapskii, 1946; Rutilevskii and Uspenskii, 1957; Wrigley and Hatch, 1976; Eberhardt and Hanson, 1978; Cherniavskii, 1984; Garrott and Eberhardt, 1987). It is easily conceivable that, at times when the mainland populations are high, the influx of continental foxes over the ice to St. Lawrence Island might be large. Emigrations from the island also appeared to take place, especially with the first arrival of the drifting pack ice in late autumn. Presumably, all or most of the immigrants and emigrants are young of the year, since they are by far the most abundant age class and they probably have no close ties to territories on land.

\section{ACKNOWLEDGEMENTS}

We thank the fox trappers of St. Lawrence Island, especially Vernon K. Slwooko, Jimmy Tooli, Clarence Pungowiyi, and Nathaniel Iya, for their aid in gathering the field data and passing on to us the native 
lore on the natural history of the St. Lawrence Island foxes. We also thank Barbara A. Fay and Brendan P. Kelly, who assisted us with data management and statistical advice respectively and, together with Lester E. Eberhardt, Erich Follmann, J. Ward Testa, and three anonymous reviewers, provided helpful comments on earlier drafts of this paper. The original field and laboratory work were supported primarily by the Animal-borne Disease Program of the U.S. Public Health Service's Arctic Health Research Center in Anchorage, Alaska, and the preparation of this report was made possible by support in part from the School of Fisheries and Ocean Sciences, University of Alaska, and in part from the Parasitology Program of the National Institute of Allergy and Infectious Diseases, U.S. Department of Health and Human Services, under grant No. R01 Al15172-07.

\section{REFERENCES}

BRADLEY, F.W., SECORD, D., and PRINS, L. 1981. Age determination in the arctic fox (Alopex lagopus). Canadian Journal of Zoology 59:1976-1979.

BRAESTRUP, F.W. 1941. A study on the arctic fox in Greenland. Meddelelser om Grønland 131. $101 \mathrm{p}$.

CHAPSKII, K.K. 1946. Mammals of the high latitudes of the Arctic Ocean. In: Transactions of the drift expedition of the Northern Sea Route Administration on the icebreaker $S$. Sedov in 1937-1940. Tom 3. Moscow-Leningrad: Glavsevmorput'. 14-18. In Russian.

CHERNIAVSKII, F.B. 1984. Mammals of the far northeast of Siberia. Moscow: Nauka. 388 p. In Russian.

CHERNIAVSKII, F.B., and DOROGOI, I.V. 1981. Ecology of the arctic fox. In: Krivosheev, V.G., ed. Ecology of the mammals and birds of Wrangel Island. Vladivostok: Akademiia Nauk SSSR. 82-98. In Russian.

CHESEMORE, D.L. 1972. History and economic importance of the white fox, Alopex, fur trade in northern Alaska, 1798-1963. Canadian FieldNaturalist 86:259-267.

CHIRKOVA, A.F. 1958a. A preliminary method of forecasting changes in numbers of arctic foxes. Translations of Russian Game Reports 3:29-49. Ottawa: Canadian Wildlife Service.

1958b. Experiment in mass visual census and forecasting the harvest of arctic foxes (1944-49). Translations of Russian Game Reports 3:101164. Ottawa: Canadian Wildlife Service.

CHITTY, H., and ELTON, C. 1937. Canadian arctic wild life enquiry, 1935 36. Journal of Animal Ecology 6:368-385.

EBERHARDT, L.E., and HANSON, W.C. 1978. Long-distance movements of arctic foxes tagged in northern Alaska. Canadian Field-Naturalist 92:386-389.

ELTON, C. 1942. Voles, mice and lemmings: Problems in population dynamics. Oxford: Clarendon Press. 496 p.

FAY, F.H. 1973. The ecology of Echinococcus multilocularis Leuckart, 1863, (Cestoda: Taeniidae) on St. Lawrence Island, Alaska. I. Background and rationale. Annales de Parasitologie Humaine et Comparee 48:523-542.

FAY, F.H., and STEPHENSON. R.O. 1989. Annual, seasonal, and habitatrelated variation in feeding habits of the arctic fox (Alopex lagopus) on St. Lawrence Island, Bering Sea. Canadian Journal of Zoology 67:1986-1994.

GARROTT, R.A., and EBERHARDT, L.E. 1987. Arctic fox. In: Novak, M., Baker, J.A., Obbard, M.E., and Malloch, B., eds. Wild furbearer management and conservation in North America. Toronto: Ontario Ministry of Natural Resources. 395-406.
GRUE, H., and JENSEN, B. 1976. Annual cementum structures in canine teeth of arctic foxes, Alopex lagopus (L.), from Greenland and Denmark. Danish Review of Game Biology 10(3):1-12.

LINDSTRÖM, E. 1981. Reliability of placental scar counts in the red fox (Vulpes vulpes L.) with special reference to fading of the scars. Mammal Review 11:137-149.

MACPHERSON, A.H. 1969. The dynamics of Canadian arctic fox populations. Report series no. 8. Ottawa: Canadian Wildlife Service. 52 p.

MURIE, O.J. 1936. Notes on the mammals of St. Lawrence Island, Alaska. In: Geist, O.W., and Rainey, F.G., eds. Archaeological excavations at Kukulik, St. Lawrence Island, Alaska. Fairbanks: University of Alaska, Fairbanks. Miscellaneous Publications 2. 337-346.

NOVIKOV, B.V. 1985. Arctic fox: North of the far east. In: Nasimovich, A.A., and Isakov. IU.A., eds. Commercial animals of the USSR and their environment: Arctic fox, red fox, and raccoon dog. Moscow: Nauka. 5972. In Russian.

PEDERSEN. A. 1930. Fortgesetzte Beiträge zur Kenntnis der Säugetier und Vogelfauna der Ostkuiste Grønlands. Meddelelser om Grønland 77: $341-507$.

PITELKA, F.A. 1973. Cyclic pattern in lemming populations near Barrow. Alaska. In: Britton, M.E., ed. Alaskan arctic tundra. Montreal: Arctic Institute of North America. Technical Paper No. 25. 199-215.

RAUSCH, R. 1953. On the land mammals of St. Lawrence Island, Alaska. Murrelet 34:18-26.

1958. Some observations on rabies in Alaska, with specific reference to wild Canidae. Journal of Wildlife Management 22:246-260.

1968. Zoonotic diseases in the changing Arctic. Archives of Environmental Health 17:627-630.

. 1972. Observations on some natural-focal zoonoses in Alaska. Archives of Environmental Health 25:246-252.

1986. Life-cycle patterns and geographic distribution of Echinococcus species. In: Thompson, R.C.A., ed. The biology of Echinococrus and hydatid disease. London: George Allen and Unwin. 44-80.

RAUSCH, R., and SCHILLER, E.L. 1956. Studies on the helminth fauna of Alaska. XXV. The ecology and public health significance of Echinococcus sibiricensis Rausch \& Schiller, 1954, on Si. Lawrence Island. Parasitology 46:395-419.

RAUSCH, R., FAY, F.H., and WILLIAMSON, F.S.L. 1990. The ecology of Echinococcus multilocularis (Cestoda: Taeniidae) on St. Lawrence Island. Alaska. II. Helminth populations in the definitive host. Annales de Parasitologie Humaine et Comparee 65:131-140.

RUTILEVSKII, G.L., and USPENSKII, S.M. 1957. The fauna of mammals and birds of the central Arctic (based on observations from drift stations). Trudy Arkticheskogo Nauchno-issledovatcl'skogo Instituta 205:5-18. In Russian.

SECORD, D.C., BRADLEY, J.A., EATON, R.D., and MITCHELL, D. 1980. Prevalence of rabies virus in foxes trapped in the Canadian Arctic. Canadian Veterinary Journal 21:297-300.

SHIBANOV, S.V. 1951. Dynamics of numbers of the arctic fox in connection with conditions of reproduction, food, and migrations. Trudy Vsesoiuznogo Naucho-issledovatel'nogo Instituta Okhotnogo Promysla 11:57-75. In Russian.

SMIRNOV, V.S. 1968. Analysis of arctic fox population dynamics and methods of increasing the arctic fox harvest. Problemy Arktiki 11:81-101. In Russian.

VIBE, C. 1967. Arctic animals in relation to climatic fluctuations. Meddelelser om Gronland 170(5). 227 p.

WRIGLEY, R.E., and HATCH, D.R.M. 1976. Arctic fox migrations in Manitoba. Arctic 29:147-158. 